The presence or absence of crystals, then, seems to bear no particular relation to the environment of the animals. Is it possible that the hardening of the chitin has to be done by calcium carbonate if the usual nitrogenous material is not available ? It can scarcely be because the calcium is only occasionally available.

Another interesting point is that all members of the same family do not necessarily behave in the same way. Thus some of the Dexaminidæ, Aoridæ and Photidæe have crystals and some have not. (It has to be noted that, while the skin of Leptocheirus pilosus Zaddach shows no structure, that of $L$. hirsutimanus (Bate) shows a reticular network similar to that of Amphithoe rubicata (Montagu). This, however, is a matter quite distinct from that of the crystals.)

The rate of crystal deposition in newly moulted individuals is extremely rapid. Gammarus pulex (L.) kept in Inormal tap-water in the laboratory showed the usual crystals in the newly moulted skin. This process was watched, and five minutes after its completion the animal was killed and its new skin examined. It was found that the crystals were well developed, especially towards the posterior end of the animal (see Fig. a). Anteriorly, crystallization was not complete-the crystals were in the growing stage; the growth had started from centres and was passing outwards. At the edge of the piece examined the crystals had reached their normal size, but away from the edge the crystals growing from their centres had not met. Twenty-four hours after moulting, the skin had a complete layer of erystals which, however, does not mean that no more deposition would take place.

The time necessary for calcification seems to be much shorter than that suggested by Schumann', who estimated it at seventy-two hours after moulting.

I can find no evidence to show that calcium is withdrawn from the skin before moulting takes place. Therefore, unless it is stored in some other part of the body, the calcium necessary for the new skin must be drawn from the water or from the foodplants. It has been impossible to get samples of either from Lough Sure, but specimens of water, weed and Gammarus pulex from an acid loch in Inverness-shire showed that, though the water was $p \mathbf{H} 6 \cdot 2$ and the hardness $2 \cdot 7$ parts of calcium carbonate per 100,000 of water, and the calcium (reckoned as $\mathrm{CaCO}_{3}$ ) in the plants was 2.05 per cent, there were crystals present in the Gammarus. Thus, though the water contained little calcium, the foodplants contained an abundant supply. Allowing for the other possible salts present (for example, those of sodium, potassium and magnesium) the concentration of $\mathrm{CaCO}_{3}$ may well be below the solubility of this salt in neutral waters.

It has also been noticed that individuals of a species taken from the south coast of England may have crystals, while those of the same species taken from the north of Scotland may be without crystals. This has been found in the case of Calliopius crenulatus Chev. and Fage, and Nototropis schuammerdami (M.-Edw.).

It is hoped to return to these investigations when conditions return to normal.
Dept. of Biology,
D. M. REID.

Harrow School,

Middlesex.

1 Schumann, F., Zool. Jahrb. (Physiol.), 44 (1928)

\section{Winter Sources of Vitamin C}

IN view of the scarcity, in Great Britain, of vitamin $\mathrm{C}$ from natural sources during the months of January, February and March, it is suggested that the following analytical data on small, hardy plants may be of some interest in problems of human nutrition. The plants were examined under the same conditions and compared with two samples of watercress purchased in the open market.

Vitamin C was determined by titration with 2 : 6 dichlorophenol indophenol, and the results shown in the accompanying table were obtained:

\begin{tabular}{|c|c|c|c|c|}
\hline & Sample & $\begin{array}{l}\text { Classifica- } \\
\text { tion }\end{array}$ & $\begin{array}{c}\text { Date } \\
\text { analysed }\end{array}$ & $\begin{array}{c}\text { Vitamin C as } \\
\text { ascorbic acid per } \\
100 \text { gm. of fresh } \\
\text { material }\end{array}$ \\
\hline 1 & $\begin{array}{l}\text { Australian } \\
\text { cress }\end{array}$ & $\begin{array}{l}\text { Lepidium } \\
\text { (? sativum) }\end{array}$ & March 4 & 148 mgm. \\
\hline 2 & $\underset{\text { cress }}{\text { American }}$ & $\begin{array}{c}\text { Barbarea } \\
\text { verna }\end{array}$ & March 31 & $108 \mathrm{mgm}$. \\
\hline 3 & $\begin{array}{l}\text { Italian corn } \\
\text { salad }\end{array}$ & $\begin{array}{l}\text { Valerianella } \\
\text { eriocarpa }\end{array}$ & March 4 & $93 \mathrm{mgm}$. \\
\hline 4 & $\begin{array}{l}\text { Nüsslisalat } \\
\text { (Swiss) }\end{array}$ & $\begin{array}{l}\text { Valerianella } \\
\text { olitoria }\end{array}$ & $\begin{array}{l}\text { February } 18 \\
\text { and March } 23\end{array}$ & $\begin{array}{l}55 \mathrm{mgm} . \\
84 \mathrm{mgm} .\end{array}$ \\
\hline 5 & Watercress & $\begin{array}{l}\text { Nasturtium } \\
\text { officinale }\end{array}$ & $\begin{array}{l}\text { February } 13 \\
\text { and March } 4\end{array}$ & $\begin{array}{l}37 \text { mgm. } \\
54 \text { mgm. }\end{array}$ \\
\hline
\end{tabular}

In addition the Nüsslisalat and Italian corn salad were tested for riboflavin by the microbiological method of Snell and Strong, and were found to give a positive response to the growth of Lactobacillus Casei $\varepsilon$ under the prescribed conditions of the test, though we are not prepared at this stage to give definite assay figures for these samples.

The seeds of the two cresses and the Italian corn salad. were bought some years ago in Great Britain, and are most prolific when grown in garden soil and well established. The Nüsslisalat was obtained by Miss V. Crowe from the Bernese Oberland, where it grows all the year round and is a constant ingredient of winter salads. It is easily grown here and flourishes during the hardest winters.

Although Nüsslisalat and corn salad have a somewhat lower vitamin $\mathrm{C}$ content than the other plants, it would be possible to eat larger quantities of them as they lack the pungency of the cresses. All these plants have a good flavour and compare very favourably with watercress, which is the only really cheap salad plant available during the winter months. They have the undoubted advantage of not requiring special methods of culture and could be grown in odd corners and small gardens.

We are aware that some of the species examined are members of the natural British flora and hope to have an opportunity of examining related wild species. Dr. J. Ramsbottom of the British Museum (Natural History), and Dr. Coke of this clinic, kindly supplied the information as to nomenclature of these plants.

\section{H. Warren Crowe.}

Enid A. M. Bradford.

Charterhouse Rheumatism Clinic, 56-60 Weymouth Street, London, W.1. April 14. 